\title{
The If, How, and When of Criminal Jurisdiction - What is Criminal Jurisdiction Anyway?
}

\author{
DAN HELENIUS*
}

\section{Introduction}

Most lawyers and laymen alike would probably claim to have at least some idea as to the meaning of the concept of jurisdiction. They might say that it indicates some form of competence or authority of a legal institution or even a state. However, as aptly stated by Malanczuk: ${ }^{1}$

'Jurisdiction is a word which must be used with extreme caution. It sounds impressively technical, and yet many people think that they have a vague idea of what it means; there is therefore a temptation to use the word without stopping to ask what it means.'

In some cases, jurisdiction may refer to a certain territory on which judicial or political entities can exercise their authority, or it may simply refer to such an entity in itself. Thus, one might say that a suspect fled the jurisdiction of Finland or Sweden, but one could also refer to Finland or Sweden as jurisdictions themselves. ${ }^{2}$ Under human rights treaties, states may also have an obligation towards individuals who are within their jurisdiction, which primarily entails a requirement of effective control. ${ }^{3}$

LL.D., University Lecturer in Criminal and Procedural Law, University of Helsinki.

Malanczuk, Akehurst's modern introduction to international law (Routledge 1997) p. 109.

See Liivoja, The criminal jurisdiction of states - A theoretical primer, 7 No Foundations: Journal of Extreme Legal Positivism (2010) pp. 25-58, at 26.

According to art. 1 of the European Convention on Human Rights: 'The High Contracting Parties shall secure to everyone within their jurisdiction the rights and freedoms defined in Section I of this Convention. See e.g. Harris et al., Law of the European Convention on Human Rights (Oxford University Press 2009) pp. 804-807. 
Nevertheless, jurisdiction usually refers to the exercise of state power or authority in some form. ${ }^{4}$ In general terms, jurisdiction designates the power of a sovereign to affect the rights of persons. ${ }^{5}$ This may be done in a variety of ways, and a state's criminal jurisdiction is only one aspect of the totality of a state's sovereign powers. The fact that a state has - or claims to have - criminal jurisdiction, then implies that the state has the power to affect the rights of persons by means of criminal law, which can be indicated by the state having penal authority or a power to punish.

As we are dealing with a pronounced legal technical concept, its meaning will not only depend upon the legal context generally, but also which legal system we are examining. For instance, in Finnish legal doctrine, the equivalent to the concept of jurisdiction would be toimivalta, which can be translated as 'power to act'. As regards criminal jurisdiction, the German concept of Strafgewalt is also quite apt, as it could be translated as 'penal power' or 'authority'. In a sense, these terms are more telling than the English term jurisdiction or the Swedish term jurisdiktion, since they already semantically imply some form of power or authority.

In this article, I will give a concise overview of my understanding of the legal phenomenon of criminal jurisdiction. ${ }^{6}$ This will be done by examining the concept of criminal jurisdiction on different levels and by posing different questions. In doing so, I have attempted to integrate Nordic, German as well as international legal doctrines into the examination. The analysis is done with the full understanding that criminal jurisdiction can be perceived, analysed and defined in different ways. Accordingly, this examination only constitutes one way of looking at the matter. Neither does the article constitute an exhaustive examination of criminal jurisdiction, but rather an assortment of selected aspects I find essential for understanding criminal jurisdiction as a legal phenomenon. Some of the questions I have omitted are: the dogmatic character of the national provisions on criminal jurisdiction, criminal policy reasons for exercising criminal jurisdiction and the legal justification for certain principles of jurisdiction. Nevertheless, the article seeks to answer the question: What is criminal jurisdiction anyway?

4 See e.g. Oxman, Jurisdiction of States in Encyclopedia of Public International Law 10 (Elsevier Science Publishers B.V. 1987) p. 277, and Capps, Evans, Konstadinidis, Introduction in Asserting Jurisdiction, eds. Capps, Evans, Konstadinidis (Hart Publishing 2003) pp. xix-xx.

5 Beale, The Jurisdiction of a Sovereign State, Harvard Law Review (1923) pp. 241-262, at 241.

6 The examination is essentially an overview of some of the findings in Helenius, Straffrättslig jurisdiktion (Suomalainen Lakimiesyhdistys 2014). 


\section{Outlining the structure of criminal jurisdiction and raising the relevant questions}

As already indicated, criminal jurisdiction presupposes a special type of state power, namely the power to punish. In order for a state to claim such a normative power, the claim must also be regarded as authoritative. This can be expressed as the state having penal authority. The existence of such an authority depends on several conditions.

As a point of departure, it is important to note that criminal jurisdiction always has a national as well as an international dimension. On the national level, jurisdiction is commonly defined as the lawful competence of the state to influence the legal position of persons through the exercise of powers in different forms. ${ }^{7}$ Here, jurisdiction concerns the relationship between the state and individuals, i.e. how the state exercises its jurisdiction vis-à-vis individual persons. Lawful in this sense entails what the state is authorised to do according to its national legislation. As the principle of legality requires that all criminal offences are established through law (nullum crimen sine lege), a state cannot prima facie claim a power to punish without this power being found in its national legislation.

On the international level, jurisdiction rather concerns the relationship between states, i.e. how states exercise - or are entitled to exercise - their jurisdiction vis-à-vis other states. ${ }^{8}$ When a state establishes its criminal jurisdiction over a certain act, it is simultaneously stating that it has the right vis-à-vis all other states to penalise and punish this act. ${ }^{9}$ Since this statement involves rights and obligations between sovereign states, the foundations for the criminal jurisdiction of a state necessarily must be found in international law. As soon as an offence displays connections to more than one state, jurisdictional problems arise that would not otherwise have arisen on the national level, or that at least cannot and should not be solved without referring to international law. ${ }^{10}$

Accordingly, if we accept that jurisdiction is a question that in some way falls within a normative framework regulated by international law, every national claim to jurisdiction must accord with standards of international law. ${ }^{11}$ In other words, on the international level, penal authority then entails a subjective right to punish (ius puniendi) in the sense

See Oxman 1987 op. cit. p. 277 and Currie, International \& Transnational Criminal Law (Irwin Law 2010) p. 50.

$8 \quad$ See Currie 2010 op. cit. p. 50.

$9 \quad$ See Capps, Evans, Konstadinidis 2003 op. cit. p. xxii.

$10 \quad$ Currie 2010 op. cit. p. 50.

11 Capps, Evans, Konstadinidis 2003 op. cit. p. xxii. 
that a state is entitled to declare a certain behaviour prohibited and punishable. ${ }^{12}$ When a state exercises this subjective right, it therefore makes use of its right to punish.

Penal authority, in this sense, signifies a legal possibility and demarcates what the state normatively may do, i.e. a normative permission. Consequently, a state's actual claim to its right to punish cannot directly be inferred from the mere existence of penal authority. ${ }^{13} \mathrm{~A}$ state's right to punish in the sense of it having penal authority exists on the international level regardless of the extent to which the state actually makes use of this right. This also implies that a state can have a lawful power to punish according to its national law, but lack penal authority according to international law. ${ }^{14}$ However, within these normative boundaries set by international law, it is up to every state to decide to which extent and based on which criminal policy considerations it wishes to make use of its penal authority. ${ }^{15}$

When the state lays claim to criminal jurisdiction, it thus makes use of the penal authority it is entitled to - it exercises its right to punish. In the same way as it is essential to examine the state's criminal law on different levels, it can also be fruitful to analyse the state's criminal jurisdiction on different levels. ${ }^{16}$ Depending on which level we are examining, criminal jurisdiction may take different forms, require different standards of justification and balancing of interests and be exercised for different reasons. ${ }^{17}$

These levels are often examined by dividing the exercise of jurisdiction into three different types, roughly corresponding to the tripartite division of the state's sovereign power

12 Jeßberger, Der transnationale Geltungsbereich des deutschen Strafrechts (Mohr Siebeck 2011) pp. 8-9. In relation to individuals, the state's ius puniendi also depends on the state's claim being in conformity with fundamental principles of criminal law, such as the principle of legality and the principle of guilt, see further Jeßberger 2011 op. cit. pp. 140-164. One can also examine the state's right to extraterritorial punishment from a moral philosophical perspective, see further Chehtman, The Philosophical Foundations of Extraterritorial Punishment (OUP 2010), especially pp. 140-172.

$13 \quad$ Jeßberger 2011 op. cit., p. 8.

$14 \quad$ Currie 2010 op. cit. p. 51.

15 Jeßberger 2011 op. cit. p. 9.

16 See Träskman, Provisions on Jurisdiction in Criminal Law - The Reform of Law Caught in the Tension between Tradition and Dynamism in Criminal Law Theory in Transition, eds. Lahti and Nuotio (Finnish Lawyers' Publishing Company 1992) pp. 512-514 and cf. Jareborg, The Coherence of the Penal System in Essays in Criminal Law (Iustus förlag 1988) pp. 105-121, who divides the analysis of the penal system into the levels of criminalization, sentencing and execution.

$17 \quad$ See Restatement of Foreign Relations Law, 3d (American Law Institute Publishers 1987) p. 231. 
into legislature, judiciary and executive. This division provides us with three different forms of jurisdictional exercise: jurisdiction to prescribe, to adjudicate and to execute. ${ }^{18}$

Prescriptive jurisdiction is exercised by the legislature when creating norms, which encompasses determining the substance of the norms as well as their scope. By enacting legislation on its (national) right to punish, the state establishes its claim to penal authority through the exercise of prescriptive jurisdiction. The fact that a national legal system contains norms that forbid or require certain behaviour from individuals when outside its national territory, and penalise such behaviour, then implies that the state has jurisdiction over the behaviour in question.

Judicial jurisdiction concerns the activities of judicial bodies when deciding their respective competences and when applying and interpreting norms created by the legislature. By exercising judicial jurisdiction, the state in practice enforces its claim to penal authority as established on the legislative level. The fact that a national court may adjudicate on an offence committed abroad then implies that the court has jurisdiction over the offence.

Executive jurisdiction in its turn concerns the activities of authorities when exercising their powers to enforce and ensure observance of the law, e.g. through the use of coercive measures. ${ }^{19}$ Contrasting these aspects by the character of law they touch upon, the first component addresses an issue of substantive criminal law while the second and third components address issues of procedural law. ${ }^{20}$ On the legislative level, the state establishes its claim to penal authority through prescriptive jurisdiction. On the judicial level, the state enforces this claim through judicial jurisdiction. ${ }^{21}$

When analysing these levels, it can furthermore be useful to reshape the analysis into questions. By posing questions, the characteristics of the different levels may also reveal themselves. The main question in this case would probably be 'why': Why does the state legislate on criminal jurisdiction in a certain way? Why does the state adjudicate cer-

18 See e.g. Restatement of Foreign Relations Law, 3d op. cit. p. 231, Council of Europe, European Committee on Crime Problems, Extraterritorial Criminal Jurisdiction, Criminal Law Forum nr. 3 (1992) pp. 441-480, at 444-445 and Böse, Meyer, Schneider, Conflicts of Jurisdiction in Criminal Matters in the European Union, Volume II: Rights, Principles and Model Rules (Nomos 2014) pp. $22-23$.

19 Due to its different character as compared to prescriptive and judicial jurisdiction, I will largely disregard the question of executive jurisdiction in this article. For instance, it is largely agreed upon that states may not undertake any executive measures on the territory of other states without explicit permission. See on this matter e.g. Currie 2010 op. cit. pp. $92 \mathrm{ff}$.

20 Böse, Meyer, Schneider 2014 op. cit. pp. 23-24.

${ }_{21}$ Through the exercise of judicial and executive powers, the state can also be said to be 'enforcing' norms prescribed by the legislature. Thus, judicial and executive jurisdiction can also be categorized as 'enforcement jurisdiction', see Currie 2010 op. cit. pp. 53-54 and Böse, Meyer, Schneider 2014 op. cit. p. 23. 
tain offences when committed abroad? Why does the state e.g. enforce sentences handed down abroad? ${ }^{22}$

The question of 'why' is without doubt of utmost importance with regards to matters of criminal jurisdiction. In many ways, it is not very different from the question of 'why' we use criminal law at all: Why should we punish? Why should we criminalise certain behaviour? As regards criminal jurisdiction as an aspect of criminal law, additional questions arise due to the involvement of foreign elements: Why should we claim a right to punish acts committed abroad? As with criminal law generally, the question of 'why' as regards criminal jurisdiction encompasses a varied range not only of legal questions, but also of moral philosophical, and criminal policy questions.

In this article, I have largely opted to disregard the question of 'why' and to examine the concept of criminal jurisdiction through a slightly different set of questions, mainly focusing on matters of a more legal dogmatic character. The questions I have opted for are:

- Does the state have penal authority?

- How should the state exercise its penal authority?

- When should the state enforce its penal authority?

These questions may also be expressed as the 'if', 'how and 'when' of criminal jurisdiction.

\section{The 'if' of criminal jurisdiction - Does the state have penal au- thority?}

\subsection{The national level}

Through the exercise of prescriptive jurisdiction, the state defines which acts it finds unwanted and therefore penalised. In this way the national legislator indicates the acts over which the state lays claim to criminal appraisal, i.e. the scope of behaviour it seeks to regulate through its penal system. ${ }^{23}$ The state's claim on criminal appraisal is essentially manifested through the legislator's criminalisation of unwanted behaviour. This scope of appraisal consists of all acts over which the state lays claim to penal authority. In this way, the state confirms to which extent it makes use of the penal authority it is entitled

22 See in this sense Träskman 1992 op. cit. pp. 512-514.

23 See Zieher, Das sog. Internationale Strafrecht nach der Reform (Duncker \& Humblot 1977) pp. 21-22. 
to within the limits set by international law. ${ }^{24}$ The question of how far a state may extend its penal authority - i.e. the state's subjective right to punish - therefore differs from the question of to which extent a state actually lays claim to penal authority. ${ }^{25}$

Criminalisation in this sense, however, only implies the creation of abstract prohibitive norms, i.e. X constitutes an unwanted behaviour for which a penal threat is imposed. These abstract prohibitive norms do not automatically form a basis for national penal authority: e.g., can person $\mathrm{A}$ be punished for the act $\mathrm{X}$ if it is committed abroad? The abstract prohibitive norms, usually, tell us nothing about their applicability, as to where, by whom and against whom they are committed.

However, a state can clearly not set about punishing someone for breaching a legislation that lacks a defined ambit of application ${ }^{26}$ and individual prohibitive norms cannot be left 'empty' with regards to their scope of application ${ }^{27}$. Thus, if we accept that individual prohibitive norms tell us nothing about their concrete applicability, this question has to be settled through further regulation.

In most legal systems, the concrete applicability of individual prohibitive norms is only established through provisions on the scope of applicability of the national criminal law, i.e. what is commonly referred to as the provisions on criminal jurisdiction. ${ }^{28}$ Consequently, the applicability of individual prohibitive norms has to be examined in connection to the question of national criminal law's scope of application as a whole. By enacting rules on criminal jurisdiction, the state also determines the frames in which the abstract prohibitive norms can be applied in concreto.

When establishing the scope of application of its criminal law, the national legislator exercises criminal jurisdiction in the form of prescriptive jurisdiction. Consequently, the question of whether or not the state has penal authority at the national level has to be p. 163.

$25 \quad$ Jeßberger 2011 op. cit. pp. 13-14.

26 Hirst, Jurisdiction and the Ambit of the Criminal Law (Oxford University Press) 2003 p. 347.

27 Henrich, Das passive Personalitätsprinzip im deutschen Strafrecht (Max-Planck-Institut für ausländisches und internationales Strafrecht, 1994) p. 10.

28 Träskman 1992 op. cit. p. 511 and Jeßberger 2011 op. cit. pp. 114. It should be noted that some legal systems, such as the English system, do not have any 'general' provisions on criminal jurisdiction. Rather, national criminal law applies only within the state's territory in the absence of any specific statutory provision to the contrary. Prohibitory norms only apply extraterritorially if specific legislation creates extraterritorial liability, see Hirst 2003 op. cit. pp. 3-9. 
answered with reference to the state's national provisions on criminal jurisdiction. These provisions denote the extent to which the state lays claim to penal authority. ${ }^{29}$

In this sense, criminal jurisdiction only concerns the extent to which the national legislator claims the right to criminal appraisal of certain behaviour, without anything being said about the state's concrete claim to punishment through its national judiciary. Thus, in addition to the national legislator's claim on the state's right to criminal appraisal, the concept of jurisdiction may also refer to the national judiciary's competence to apply criminal norms as stipulated by the national legislator. ${ }^{30}$

Naturally, a state's authority to appraise certain behaviour through criminal law cannot exist alone; if penal threats are not to have more than a mere symbolic function, it must also be possible to implement them in practice. In other words, the state must also be able to enforce its claim on penal authority through the national judiciary's exercise of judicial authority. Norms prescribed on the legislative level also have to be implemented on the judicial level. ${ }^{31}$

Accordingly, the state's penal authority constitutes the basis for its judicial authority. If the state lacks penal authority, it also lacks the competence to initiate criminal proceedings since its legal system does not come into question in the first place. ${ }^{32}$ It would obviously be unfeasible for a state to enforce rules unless it has the authority to prescribe those rules. ${ }^{33}$

In order for judicial authority to exist, a concrete punishable act has to fall within the ambit of the state's claim on penal authority. As a main rule, the state establishes its penal authority by enacting legislation on the scope of application of its criminal law. This is due to the presumption that national courts only apply national criminal law. Consequently, as long as the national claim on penal authority is congruent with the scope of application of national criminal law, and as long as national courts only apply national criminal law, the provisions on the scope of application of national criminal law are also decisive for the jurisdiction of the state judiciary. The provisions on criminal jurisdiction, consequently, have a sort of dual nature: If a conduct falls within the scope of application of national criminal law, the door is also open for the national judiciary's jurisdiction. ${ }^{34}$

29 However, the scope of application of the state's criminal law is in principle distinct form the state's claim on penal authority. In theory, the state may also claim a right to punish by reference to other than national criminal legislation, see further chapter 4 .

30 See e.g. Vander Beeken et al., Finding the Best Place for Prosecution - European Study on Jurisdiction Criteria (Maklu, 2002) pp. 8-9.

Council of Europe 1992 op. cit. p. 456.

Jescheck \& Weigend 1996 op. cit. p. 163.

Oxman 1987 op. cit. pp. 277-278.

See e.g. Ambos, Internationales Strafrecht (Verlag C.H. Beck 2008) p. 3. 
In this sense, judicial authority has to be understood as an abstract form of state authority to institute legal proceedings. The rules on which national court is actually competent in the concrete case are often found in national procedural legislation, and these rules should therefore not be confused with rules on the state's penal authority. ${ }^{35}$ Accordingly, the state's jurisdiction to adjudicate has a transnational as well as a national element. In order to answer the question of judicial competence, the following questions have to be answered $:{ }^{36} 1$. Does the state have penal authority? 2 . Which national court is competent?

As a starting point, it is obviously in the interest of the state to subject all offences committed on its national territory to its penal authority. In a way, the whole penal system is constructed in consideration of the state territory. ${ }^{37}$ Within the state's own territory, national penal authority in a sense exists per definition. ${ }^{38}$ This principle of territoriality is directly derived from the international principle of territorial sovereignty ${ }^{39}$

However, the principle of territoriality does not entail exclusive territorial penal authority, and thus a prohibition for states to claim penal authority over other acts than those committed on its own territory. ${ }^{40}$ States almost invariably also claim the right to extend their penal authority to acts committed abroad. In those cases, the state's claim will inevitably affect the interests of other states and give rise to international questions that cannot be decided by reference to the state's national legal system alone.

On the judicial level, one can without doubt claim that the concrete enforcement of norms pertaining to acts committed abroad always has a more substantial impact as regards the relationship between states as well as between states and individuals. ${ }^{41}$ Consequently, the state's exercise of judicial authority over extraterritorial acts always requires further consideration and balancing of interests. ${ }^{42}$ Thus, even though the state's penal and judicial authority are in principle congruent, it is essential that these elements are analysed separately.

35 Hurtado Pozo, Droit pénal - Partie générale (Schulthess 2008) p. 63.

36 Cf. Stéfani, Levasseur, Bouloc, Procédure pénale (Dalloz) p. 489, who distinguish between 'la compétence internationale des juridictions répressives françaises' and 'la compétence nationale des juridictions répressives françaises.' ("Ce sont les règles de compétence internationale qui répondent à la première question. Les règles de competence interne répondent à la seconde.")

37 Frände, Allmän straffrätt (Forum iuris 2012) p. 309 footnote 17.

38 Ziegenhain, Extraterritoriale Rechtsanwendung und die Bedeutung des Genuine-LinkErfordernisses - eine Darstellung der deutschen und amerikanischen Staatenpraxis (Beck 1992) p. 12 .

$39 \quad$ See e.g. Jeßberger 2011 op. cit. p. 228.

$40 \quad$ Jescheck - Weigend 1996 op. cit. p. 168.

41 Tupamäki, Valtion rikosoikeudellisen toimivallan ulottuvuus kansainvälisessä oikeudessa (Finnish Branch of the International Law Association 1999) p. 22.

$42 \quad$ See further under part 5. 


\subsection{The international level}

It is often stated that characterizing the state's provisions on criminal jurisdiction as 'international criminal law' is misleading, ${ }^{43}$ since these norms are not part of any international legal order but rather of every state's national legal order. ${ }^{44}$ The norms on criminal jurisdiction only differ from other norms of criminal law in that they regulate situations with transnational or international elements, i.e. situations where other states' or the international community's interests come into play. ${ }^{45}$ Thus, the object of the norms on criminal jurisdiction can be regarded as international or transnational, while the norms themselves remain national. ${ }^{46}$

However, the state's criminal jurisdiction is, nonetheless, co-determined by standards of international law. ${ }^{47}$ Since the exercise of criminal jurisdiction affect the interests (and thus the sovereignty) of other states, the national legal order also has to take into account potential international issues that arise as a result. ${ }^{48}$ Accordingly, the state's criminal jurisdiction is not founded upon international law, but international law does confine the state's criminal jurisdiction. ${ }^{49}$ In other words, the normative boundaries for the state's penal authority are found in international law. Thus, the question of whether or not the state has penal authority not only has to be answered through the national legislation, but also at the international level.

States essentially constitute sovereign territorial entities and are as a consequence always entitled to claim criminal jurisdiction over their own territory. Today, it is largely agreed upon that states may not, however, extend their criminal jurisdiction to acts committed abroad merely at their own discretion and that this issue is, in some way, governed by international law..$^{50}$ The fundamental basis is fairly easy to formulate: states may only exercise extraterritorial jurisdiction to the extent that this does not infringe upon the sovereignty of other states. ${ }^{51}$ Obviously, a general requirement to respect the sovereignty of other states does not in itself provide us with any useful legal guidelines.

43 On the definition of international criminal law, see e.g. Satzger, Internationales und Europäisches Strafrecht (Nomos 2013) pp. $28 \mathrm{ff}$.

$44 \quad$ See e.g. Hecker, Europäisches Strafrecht (Springer 2010) p. 25.

45 See Träskman, Straffrättsliga åtgärder med främmande inslag, I. En granskning av den finska straffrättens tillämpningsområde (Juridiska föreningen i Finland 1977) p. 27 and Jescheck \& Weigend 1996 op. cit. p. 165.

$46 \quad$ Currie 2010 op. cit. p. 27.

47 Eser, in Schönke/Schröder: Strafgesetzbuch - Kommentar (Verlag C.H. Beck 2010) p. 67.

$48 \quad$ Currie 2010 op. cit. p. 20.

49 Spiermann, Moderne folkerett (Jurist- og Økonomforbundets Forlag 2006) p. 263.

$50 \quad$ See e.g. Council of Europe 1992 op. cit. p. 454.

$51 \quad$ Currie 2010 op. cit. p. 56. 
If we accept that states may not exercise jurisdiction merely at their own discretion, two distinct approaches can generally be distinguished. ${ }^{52}$ According to the first approach, states are permitted to extend their criminal jurisdiction extraterritorially as long as there is no prohibitive international rule to the contrary. In other words, that which is not prohibited is allowed..$^{53}$ This permissive approach is generally derived from the classical 'Lotus case', decided by the Permanent Court of International Justice in $1927,{ }^{54}$ where the court famously stated:

'It does not, however, follow that international law prohibits a State from exercising jurisdiction in its own territory, in respect of any case which relates to acts which have taken place abroad, and in which it cannot rely on some permissive rule of international law. ... [I]t leaves them in this respect a wide measure of discretion, which is only limited in certain cases by prohibitive rules; as regards other cases, every State remains free to adopt the principles which it regards as best and most suitable.'

According to the second and contrary approach, states are only permitted to extend their criminal jurisdiction extraterritorially if they are able to rely on a permissive rule of international law. In other words, that which is not allowed is prohibited. ${ }^{55}$ According to this restrictive approach, such permissive rules are generally presumed to be manifested in the international principles of jurisdiction. ${ }^{56}$

Although the restrictive approach would seem to be more widely accepted today, both approaches have their evident problems. The protesting state either has to point to a prohibitive rule, or the state claiming jurisdiction has to point to a permissive rule. In both cases, it can be rather cumbersome to demonstrate the existence and exact legal content of such rules. The question is whether it would not be possible to find a middle course that strives to take both approaches into account. ${ }^{57}$

Regardless of which approach one advocates, it is clear that the limitations as well as the justifications for a state's right to extraterritorial jurisdiction in some way have to be derived from their sovereignty. As a starting point, the principle of the sovereign equality of states constitutes a principle that is essential for the existence of the nation-state in its historical form. This principle entails a demand for states to respect each other's sover-

52 See e.g. Vander Beken et al. 2002 op. cit. p. 10, Reydams, Universal jurisdiction - international and municipal legal perspectives (Oxford University Press 2004) pp. 13-16 and Liivoja, An axiom of military law - Applicability of national criminal law to military personnel and associated civilians abroad (University of Helsinki, Centre of Excellence in Global Governance Research 2011) p. 59.

53 Werle \& Jeßberger, in Leipziger Kommentar zum Strafgesetzbuch - Band 1 (De Gruyter Recht 2007) pp. 402-403.

54 S.S. Lotus (France v. Turkey), 1927 PCIJ (ser. A) No. 10.

$55 \quad$ Werle \& Jeßberger 2007 op. cit. pp. 403.

$56 \quad$ See e.g. Liivoja 2011 op. cit. p. 78.

$57 \quad$ Cf. Eser 2010 op. cit. p. 68. 
eignty. ${ }^{58}$ Sovereignty in a substantive sense encompasses a state's self-determination over its so-called internal affairs. The content of a state's internal affairs can, in turn, be derived from the 'Declaration on Friendly Relations', adopted by the UN Security Council in $1970 . .^{59}$

According to this declaration, the sovereign equality of states (and their substantive sovereignty derived thereof) entails inter alia that 'Each State has the right freely to choose and develop its political, social, economic and cultural systems'. This implies that every state is entitled to freely decide upon its foreign and internal policy, and consequently also its criminal policy.

While the demand for states to respect each other's sovereignty in a positive sense entails a right for them to freely decide upon their internal affairs, there also follows a contrario a prohibition for states to intervene in each other's internal affairs (the so called principle of non-intervention).$^{60}$ In this sense, the right to extraterritorial regulation can, on the one hand, be regarded as a positive aspect of the state's substantive sovereignty, while the principle of non-intervention can be regarded as its negative aspect. ${ }^{61}$ Consequently, sovereignty in a substantive sense gives a basis for, as well as a restriction of, the state's criminal jurisdiction. ${ }^{62}$

Accordingly, a state's right to active self-determination as to its criminal policy is a part of the state's internal affairs that is protected from foreign jurisdictional interference. Thus, if a state lays claim to penal authority with regard to acts committed on the territories of other states, this would prima facie appear to be an intervention in the internal affairs of those states. ${ }^{63}$ By extending the scope of application of its criminal law beyond its territory, the national legislator essentially exercises prohibitive authority on the territories

58 Geiger, Grundgesetz und Völkerrecht (Verlag C.H. Beck 2002) p. 325. According to art. 2.1 of the Charter of the United Nations: 'The Organization is based on the principle of the sovereign equality of all its Members.'

59 Declaration of Principles of International Law Concerning Friendly Relations and Co-operation Among States in Accordance with the Charter of the United Nation, Resolution no. 2625 (XXV), 24 October 1970. See Ziegenhain 1992 op. cit. pp. 25-26.

$60 \quad$ See e.g. Ziegenhain 1992 op. cit. p. 27 and Jeßberger 2011 op. cit. p. 193.

$61 \quad$ Ziegenhain 1992 op. cit. p. 27.

$62 \quad$ Jeßberger 2011 op. cit. p. 193.

63 Tupamäki 1999 op. cit. p. 141. 
of foreign states and thereby intervenes in those states' sovereign right to regulate their internal affairs. ${ }^{64}$

However, it is clear that every foreign intervention in a state's right to self-determination cannot be regarded as a violation of the principle of non-intervention. ${ }^{65}$ Namely, the state's right to extraterritorial jurisdiction also follows from its sovereignty and right to self-determination. ${ }^{66}$

An exclusive right to territorial self-determination would e.g. prevent states from trying their own nationals for offences committed abroad or protecting themselves from offences directed at the state from abroad. ${ }^{67}$ If all claims to penal authority over acts committed abroad would invariably be questionable, every state would be obligated to delimit its legislation to its own territory. ${ }^{68}$ It is clear that the legitimate interests of states often overlap, e.g. as regards territory and nationals.

Nonetheless, a state's extension of its penal authority outside its own territory clearly affects the sovereign interests of other states. ${ }^{69}$ Extraterritorial jurisdiction can, consequently, never constitute an exclusively internal state question, as the authority of the state's extraterritorial claim is dependent upon its compatibility with international law standards. ${ }^{70}$ However, if extraterritorial jurisdiction - within certain limits - is permissible, the positive aspect of the state's substantive sovereignty cannot be absolute and exclusive either; states consequently do not possess an exclusive jurisdiction over their

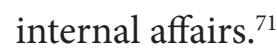

Rather, the decisive question must be whether or not the intervention in the internal affairs of other states can be regarded as justified or not. Accordingly, the question is not

64 Ambos 2008 op. cit. p. 20. It might certainly be true that real controversies only tend to arise when courts actually attempt to enforce the state's claim on penal authority on the judicial level. Nevertheless, the need for justification with regard to international law already arises on the legislative level, i.e. when the state lays claim to penal authority. As Oxman 1987 op. cit. p. 278 states: "The mere enactment of a statute or delivery of a summons may give rise to international protest because enforcement is implicitly threatened". Of the same opinion also Je $\beta$ berger 2011 op. cit. p. 214 and Asp, The Substantive Criminal Law Competence of the EU (Skrifter utgivna av Juridiska fakulteten vid Stockholms universitet 2012) p. 41.

65 Council of Europe 1992 op. cit. p. 459 and Ziegenhain 1992 op. cit. p. 35.

66 This is evident already from the Lotus case, where the Permanent Court of International Justice stated that a state's 'title to exercise jurisdiction rest in its sovereignty'. See also Henrich 1994 op. cit. p. 17.

$67 \quad$ Council of Europe 1992 op. cit. p. 460.

$68 \quad$ See Currie 2010 op. cit. p. 52.

$69 \quad$ Jeßberger 2011 op. cit. p. 192.

$70 \quad$ See Träskman 1977 op. cit. pp. 209-210 and Henrich 1994 op. cit. p. 12.

71 Rosswog, Das Problem der Vereinbarkeit des aktiven und passiven Personalgrundsatzes mit dem Völkerrecht (Ludwig Röhrscheid Verlag 1965) p. 138. 
about an absolute prohibition against intervening in the internal affairs of other states, but rather a prohibition against unjustified intervention. ${ }^{72}$

In the current situation, we are dealing with a collision between two principles, i.e. the principle of active self-determination and the principle of non-intervention. If we regard principles as requirements of optimisation, this implies that these two principles have to be optimised in relation to each other, meaning that the sovereign claim of each state respectively has to be realised to the widest extent possible. ${ }^{73}$

Thus, the positive and negative aspect of the state's substantive sovereignty mutually restricts each other. ${ }^{74}$ The principle of sovereign equality of states neither entails a complete prohibition against nor a limitless authorisation of extraterritorial jurisdiction. Neither of these two components may be realised at the other's expense, but have to be brought in harmony through optimisation.

Regardless of how one approaches the question of the state's right to extraterritorial jurisdiction, a state must in any case be able to identify a sufficient interest between itself and the object of its assertion of jurisdiction. ${ }^{75}$ By extending its national penal authority beyond its own borders, the state exercises prohibitive authority within the territory of foreign states. Such an intervention in other states' self-determination has to be justified by reference to a connection that expresses a sufficient interest between the extraterritorial circumstance and the state laying claim to extraterritorial penal authority. This demand is manifested in the so-called 'doctrine of meaningful connection' that requires a sufficient interest-relation between the state enacting extraterritorial legislation and the extraterritorial circumstance it applies to. ${ }^{76}$ By combining the principle of non-intervention with a requirement of meaningful connection, the former gains clearer contours and legal preciseness. ${ }^{77}$ If a state extends its penal authority abroad without being able to demonstrate a meaningful connection, it violates the principle of non-intervention and, accordingly,

Council of Europe 1992 op. cit. p. 459.

Ziegenhain 1992 op. cit. pp. 39-40. On principles as requirements of optimisation in general, see Alexy, Theorie der Grundrechte (Suhrkamp 1986) pp. 75 ff.

Ziegenhain 1992 op. cit. pp. 51.

Oxman 1987 op. cit. pp. 278.

Alternative expressions used include 'real link', 'sufficient nexus' and 'genuine connection'. See e.g. Cameron, The Protective Principle of Criminal Jurisdiction in Nordic Criminal Law, in Criminal Law Theory in Transition, eds. Lahti and Nuotio (Finnish Lawyers' Publishing Company 1992) p. 567, Liivoja 2011 op. cit. pp. 72-74 and Satzger, International and European Criminal Law (C.H.Beck, Hart \& Nomos 2012) pp. 12-13. On the requirement of a genuine connection between state and nationals, see also International Court of Justice, Judgment of 6 April 1955 Nottebohm (Liechtenstein v. Guatemala), pp. 23 ff.

77 Henrich 1994 op. cit. pp. 17-18. 
international law. ${ }^{78}$ Thus, if we attempt to find a general international prohibition in accordance with the Lotus case, this prohibition has to be the principle of non-intervention.

The principle of non-intervention thus entails an extensive restriction of the state's right to extraterritorial jurisdiction, and is violated if no meaningful connection between the circumstances and the state in question is found (negative requirement). Vice versa: A state may extend its penal authority if a meaningful connection is at hand (positive requirement). ${ }^{79}$

If one accepts this understanding, the permissive and restrictive approach can essentially be seen to lead to the same result. ${ }^{80}$ Extraterritorial jurisdiction is then permissible when no international prohibition is at hand. In this regard, the principle of non-intervention constitutes a general prohibition that is violated when no meaningful connection can be demonstrated. This, vice versa, implies that states have to be able to justify their extraterritorial jurisdiction by reference to a meaningful connection.

Consequently, if a meaningful connection is at hand, the principle of non-intervention has to yield to another state's sovereignty based claim on jurisdiction. In want of such a connection, the principle of non-intervention outweighs the interests of the state claiming jurisdiction. In my view, it is the task of the state claiming jurisdiction to demonstrate the existence of a meaningful connection, rather than the task of the state protesting against the jurisdictional claim to disprove that such a connection exists. ${ }^{81}$

The doctrine of meaningful connection can, accordingly, be regarded as a legal concretisation of the limits of the principle of non-intervention. The existence of a meaningful connection implies that the state claiming extraterritorial jurisdiction is not unjustifiably intervening in the internal affairs of another state.

One of the problems with the doctrine of meaningful connection, however, is establishing which connections can in fact be regarded as sufficiently 'meaningful'. The meaningfulness of an invoked connection has to display a minimum of international consensus by reference to general sources of international law, such as international customary law and general principles of law recognised by civilised nations..$^{82}$ In general, it is presupposed

78 See e.g. Henrich 1994 op. cit. p. 18, Ambos 2008 op. cit. p. 21 and Satzger 2013 op. cit. p. 36.

79 Ziegenhain 1992 op. cit. p. 47 and Werle - Jeßberger 2007 op. cit. p. 402.

80 Cf. Werle - Jeßberger 2007 op. cit. p. 403.

81 See Bianchi, Comment to Harold G. Maier (Jurisdictional Rules in Customary International Law), in Extraterritorial Jurisdiction in Theory and Practice, ed. Meessen (Kluwer Law International 1996) p. 90. Of a different opinion, Jeßberger 2011 op. cit. pp. 213-214.

82 See Bianchi 1996 op. cit. p. 90 . Art. 38 of the Statute of the International Court of Justice contains what is generally viewed as the primary sources of international law, see Currie 2010 op. cit. pp. 29-30. 
that the 'principles' of jurisdiction refer to such connections that display a minimum of international consensus. ${ }^{83}$

\subsection{Principles of jurisdiction}

Any examination of jurisdictional questions would seem inadequate without some reference to the 'principles' of jurisdiction. When discussing these principles, one commonly refers to the principles formulated in the 'Harvard Draft Convention on Jurisdiction with Respect to Crime of $1935:{ }^{84}$ the territorial principle, the nationality principle (or active personality principle), the protective principle, the universality principle and the passive personality principle. ${ }^{85}$ Other principles often referred to are the flag principle and the principle of representational jurisdiction. ${ }^{86}$ What all these principles have in common, is that they are presupposed to indicate some form of connection, based on which a state is authorised to establish its jurisdiction.

However, the normative significance of these principles is disputed. On the one hand, it is clear that international law does not provide any clear-cut jurisdictional rules. ${ }^{87} \mathrm{On}$ the other hand, if one accepts that states do not have an unrestricted right to extend their criminal jurisdiction, these principles cannot completely lack normative power, i.e. the presumption is that these principles in some way govern the state's exercise of criminal jurisdiction. In order to make it possible to examine these principles, one must, as a starting basis, make a distinction between national principles of jurisdiction and international principles of jurisdiction. ${ }^{88}$

On the national level, jurisdictional norms in general take the form of rules that prescribe under which conditions national criminal law applies, and thereby establish the state's claim on penal authority. Each of these rules prescribes a connection or condition under which the national criminal law applies (e.g. the nationality of the offender or victim or the nature of the offence). This makes it possible to categorise the rules according to different labels, commonly referred to as principles. For instance, a rule stating that national criminal law applies to offences committed outside the state by its nationals can be categorised under a national principle of active personality. Accordingly, the national principles indicate to which extent, and based on which grounds, national criminal law is applicable, and are thus always bound to a specific national legal order.

$83 \quad$ See e.g. Jeßberger 2011 op. cit. p. 205.

84 Harvard Research in International Law: Draft Convention on Jurisdiction with Respect to Crime, Supplement to the American Journal of International Law (1935) pp. 437-635.

85 See ibid. p. 445.

${ }^{86} \quad$ See further e.g. Currie 2010 op. cit. pp. 56 ff. and Satzger 2013 op. cit. pp. 36 ff.

$87 \quad$ Currie 2010 op. cit. p. 79.

$88 \quad$ See Jeßberger 2011 op. cit. p. 32. 
These national principles are the results of attempts to identify and systematise overall elements in the national rules of jurisdiction. They therefore have a descriptive function. They are used to describe, compare and analyse the jurisdictional rules of states. ${ }^{89}$ They thus provide an analytical framework that makes it possible to examine and classify national jurisdictional norms and thereby provide information on the extent to which the national penal order lays claim to penal authority. This makes it possible to submit that a national jurisdictional rule expresses or regulates a certain principle..$^{90}$

The international principles, on the other hand, demarcate the area in which international law allows the establishment of penal authority. ${ }^{91}$ They indicate when a minimum of international consensus can be seen to exist as to the acceptance of certain connections. ${ }^{92}$ The international principles are thus often referred to as 'legitimate' connections that give a concrete delimitation to the expression 'meaningful connection' and constituently establish which connections the national legislator may refer to when determining the state's penal authority ${ }^{93}$ They therefore also have a normative function.

However, this theoretically advisable distinction between national and international principles of jurisdiction is complicated in practice due to the interaction that exits between these elements. This interaction becomes clear when one considers the process behind the international principles as a part of international law. ${ }^{94}$ Namely, the international principles must be seen to have developed from the national principles as they, in turn, have been enshrined in national legislation. This process has its roots in the general sources of international law, such as international customary law and general principles of law. ${ }^{95}$ There is thus a continuous process of interaction between the national and international dimensions of these principles. ${ }^{96}$

In the course of their development, the international principles have become detached from the national principles and have acquired an independent meaning as international norms of permissibility. ${ }^{97}$ Thus, they indicate the extent to which states are normatively permitted to establish a national claim to penal authority. They are based on, and form typical examples of, balancing a state's active self-determination against the principle of

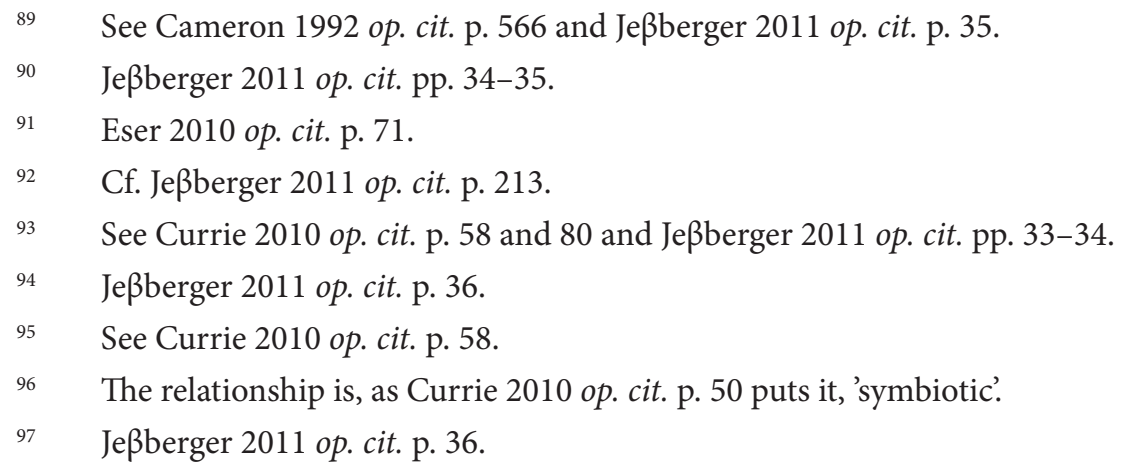


non-intervention. As such, they facilitate the need of national legislators and judiciaries to conduct a new exercise in balancing these two interests in every single case. ${ }^{98}$

Accordingly, a state's exercise of jurisdiction may very well be in accordance with its national law on jurisdiction but nevertheless be contrary to international jurisdictional standards. ${ }^{99}$ National rules on jurisdiction are not sufficient per se to establish meaningful connections, since they are not necessarily prescribed in consideration of the principle of non-intervention, but rather follow national criminal policy considerations and interests. ${ }^{100}$ However, as long as a national rule can be subsumed under an accepted international principle of jurisdiction, there is a strong presumption that the rule gives expression for a connection that is meaningful. ${ }^{101}$

The question still remains of whether the international principles of jurisdiction should be regarded as exhaustive norms of permission, or whether states may also extend their penal authority beyond the existing principles or refer to new principles, as long as they are able to demonstrate the existence of a meaningful connection. Some scholars contend that states must always be able to refer to one of the accepted principles in order to justify their jurisdictional claim, ${ }^{102}$ while others propose that states may very well refer to connections outside of these principles, as long as they are able to demonstrate their meaningfulness ${ }^{103}$.

In my view, states should in principle be able to invoke connections that fall outside the accepted principles of jurisdiction, as long as they are able to demonstrate a sufficient international basis for them, i.e. a meaningful connection. In theory, national jurisdictional rules might very well give rise to new internationally accepted principles of jurisdiction. International law is not, after all, a static legal area, but develops concurrently with international agreements, state practice and general principles of law. In this case, I would, however, contend that it is up to the state extending its penal authority beyond the accepted principles to demonstrate the existence of a sufficient international consensus as to the connection it bases its jurisdiction upon.

$98 \quad$ Reydams 2004 op. cit. pp. 23-24.

$99 \quad$ Currie 2010 op. cit. pp. 51.

$100 \quad$ Ambos 2008 op. cit. p. 24 and Hecker 2010 op. cit. p. 30.

101 I will not discuss further which individual principles can actually be considered accepted under international or European law. On this issue, see e.g. Ambos 2008 op. cit. pp. 23 ff. and Böse, Meyer \& Schneider 2014 op. cit. pp. 43 ff.

102 See e.g. Jeßberger 2011 op. cit. pp. 212-213.

103 See e.g. Ziegenhain 1992 op. cit. p. 7 and Henrich 1994 op. cit. p. 21. Cf. also Böse \& Meyer, Die Beschränkung nationaler Strafgewalten als Möglichkeit zur Vermeidung von Jurisdiktionskonflikten in der Europäischen Union, 5 Zeitschrift für Internationale Strafrechtsdogmatik (2011) pp. 336-344, at 338. 
On the other hand, one should not underestimate the safety that the established principles offer the national legislator. ${ }^{104}$ By basing the national law on jurisdiction on the accepted principles of jurisdiction - and keeping within their limits - the national legislator ensures a strong presumption of the national rules' compatibility with international standards. ${ }^{105}$

\section{The 'how' of criminal jurisdiction - How should the state exer- cise its penal authority?}

The fact that a state establishes its penal authority over certain behaviour only implies prima facie that the state lays claim to criminal appraisal of this behaviour, i.e. a claim on the right to penalise and punish. The question of 'how' - as opposed to 'if' - this appraisal should be conducted is principally not answered until a specific criminal law is declared applicable. Accordingly, the question of the national penal order's scope of appraisal is distinct from the question of the scope of application of the national criminal law. By establishing the scope of application of the state's criminal law, the national legislator indicates the area that is to be appraised by way of the criminal law in question. The national criminal legislation and the provisions that are part of it are declared as standards for the appraisal of specific circumstances. ${ }^{106}$

One often finds that the national provisions on criminal jurisdiction are equated with the provisions on the scope of application of national criminal law. Jurisdiction in this sense concerns the state's criminal appraisal of unwanted behaviour, which is manifested through the national criminal law. This also explains why the law on criminal jurisdiction in German legal doctrine is often referred to as Strafrechtsanwendungsrecht, which can roughly be translated as 'law on the use of criminal law.' ${ }^{107}$ As no comparable term seems to exist in English, it appears that the best way to indicate the legal area covering a state's provisions on criminal jurisdiction is simply to refer to it as the law on criminal jurisdiction.' 108

The fact that the scope of application of the state's criminal law as a clear principal rule coincides with the national claim on penal authority should, however, not be seen as

$104 \quad$ Henrich 1994 op. cit. p. 23.

105 See also O'Keefe, Universal Jurisdiction - Clarifying the Basic Concept, Journal of International Criminal Justice (2004) pp. 735-760, at 738 footnote 12.

$106 \quad$ Jeßberger 2011 op. cit. pp. 12-14.

$107 \quad$ See e.g. Satzger 2013 op. cit. p. 31.

108 For the Swedish doctrine, see also e.g. Asp, Internationell straffrätt (Iustus Förlag 2011) p. 26, who uses the term 'jurisdiktionsrätt'. 
self-evident. In theory, a state's claim on penal authority can also be realised through the use of other than national criminal law (e.g. foreign or supranational criminal law). ${ }^{109}$

The national provisions on criminal jurisdiction would thus not only concern the matter of the scope of application of the state's criminal law, but also the - chiefly independent question of the national claim on penal authority. ${ }^{110}$ In this sense, the national provisions on criminal jurisdiction answer two distinct questions: 'does the state have penal authority?' ('if') and 'according to which norms shall this authority be exercised?' ('how') ${ }^{111}$

Accordingly, a state's claim on criminal appraisal of certain circumstances is established directly through the declaration of a certain criminal law as applicable, regardless of which criminal law. ${ }^{12}$ Hence, the state's prescriptive jurisdiction does not only concern the demarcation of the scope of application of national criminal law, but also the demarcation of national penal authority. ${ }^{113}$ In theory, this implies that national penal authority can be wider than the scope of application of national criminal law. ${ }^{114}$

However, this distinction between national penal authority and scope of application of national criminal law can largely be disregarded, since it is of importance only if national courts are able to apply other legislation than national criminal law. ${ }^{115}$ As long as this is not the case, the state's claim on penal authority can, consequently, not be more extensive than scope of application of national criminal law. Thus, the question of national penal authority and the scope of application of national criminal law are determined by the same norms. The fact that national criminal law is declared applicable to extraterritorial behaviour under certain conditions simultaneously entails that national penal authority is established under the corresponding conditions. ${ }^{116}$

Admittedly, states are often obliged to take foreign criminal law in consideration when assessing a potential jurisdictional requirement of double criminality. However, even though the state's penal authority is made conditional upon the requirement of double

109

113 Eser 2010 op. cit. p. 66.

$114 \quad$ Jeßberger 2011 op. cit. p. 15.

115 Henrich 1994 op. cit. p. 9 footnote 2 and Ambos 2008 op. cit. p. 3.

116 See e.g. Satzger 2013 op. cit. p. 32.

Jeßberger 2011 op. cit. p. 15. rikosoikeuden oppikirja. Ensimmäinen osa. Yleiset opit (Helsinki 1940) pp. 66-67.

This twofold character of the national provisions on criminal jurisdiction is widely accepted at least in German criminal law doctrine, see e.g. Jescheck - Weigend 1996 op. cit. pp. 163-164.

Jeßberger 2011 op. cit. p. 14. This distinction between penal authority and scope of application of the national criminal law is also found Finnish criminal law doctrine, see Serlachius, Suomen

eumann, Normtheoretische Aspekte der Irrtumsproblematik im Bereich des "Internationalen Strafrechts", in Grundfragen staatlichen Strafens - Festschrift für Heinz Müller-Dietz zum 70. Geburtstag, eds. Britz et al. (Verlag C.H. Beck 2001) p. 600 and Je $\beta$ berger 2011 op. cit. p. 14. 
criminality in some situations; this does not amount to actually applying foreign criminal law, but rather implies a potential bar to the application of national law. ${ }^{117}$

Nevertheless, the fact that states as a clear general rule only implement their penal authority by way of national criminal law does not necessary signify that this distinction between penal authority and applicable criminal law is merely theoretical. That a legal order claims a right to punish through the application of other legislation than national law is not an impossibility and has also occurred in practice. ${ }^{118}$ In this case, the state does lay claim to penal authority of its own, but the criminal appraisal is done through the application of other legal sources than national criminal law. ${ }^{119}$ This was e.g. the case until 2006 according to article 5 of the Swiss criminal code: ${ }^{120}$

\begin{abstract}
'Whoever commits a felony or misdemeanour against a Swiss national abroad is to be punished according to Swiss law, provided the act is also criminal under the law of the territory where it was committed, if he is present in Switzerland and will not be extradited or if he is extradited to the Confederation because of this act. If the law of the place of the commission is more favourable to the offender, it is to be applied.'
\end{abstract}

In this case, the law on criminal jurisdiction could - similarly to international private law - be regarded as a form of collision law, enabling a choice between different legal orders in cases of overlap. ${ }^{121}$ But as long as this is not the case, criminal jurisdiction does not only constitute a question of procedural forum. To distinguish the question of forum from the question of choice of law - as is common in international private law - would therefore be misleading. In criminal law, the forum does not determine which law to apply, but the applicable law rather determines the forum. ${ }^{122}$ If national criminal law is not applicable - i.e. if the state lacks a claim to penal authority - the state also lacks judicial authority. The law on criminal jurisdiction does not regulate what can be understood as conflicts between different national legal orders, only the extent to which the national legal order is applicable. ${ }^{123}$

However, in an increasingly integrated Europe, one could question whether it in the long run would be conceivable to create a system where the applicable criminal law - at least as regards certain offences - would not be dependent upon the trial state. The Swiss and

117 See van den Wyngaert, Double Criminality as a Requirement to Jurisdiction, in Double criminality - Studies in international criminal law, ed. Jareborg (Iustus Förlag 1989), p. 44.

$118 \quad$ Neumann 2001 op. cit. p. 599.

$119 \quad$ Jeßberger 2011 op. cit. p. 15.

120 See Satzger 2012 op. cit. p. 8. A similar provision was earlier also found in the German criminal code, see Jescheck \& Weigend 1996 op. cit. p. 164.

$121 \quad$ Satzger 2012 op. cit. p. 8.

122 See Lombois, Droit pénal international (Dalloz 1979) pp. 8-9.

123 Satzger 2012 op. cit. pp. 8-9. 
German examples above demonstrate that this would not be a completely new concept. The general development within the EU undoubtedly raises the question of when the EU can be regarded as having federal characteristics to the extent that the member states are able to apply some form of legal framework on the choice of law. Consequently, national courts would be able to apply other than domestic law not only in civil cases, but also in criminal cases. Such a system can undeniably be seen to have some benefits. ${ }^{124}$

This would namely enable the application of the substantive penal order that has the closest connection to the case, irrespective of forum. ${ }^{125}$ This could first of all remove the current reason for unequal treatment with regards to criminal sentencing, which can e.g. bring about the situation that two persons who commit an offence together, but thereafter flee to different member states, can receive entirely different punishments. Second of all, it could contribute to removing some of the misgivings that exist especially with regards to the European arrest warrant. The state with the most repressive penal order or the state that first renders a final decision in accordance with the 'first come first served' principle would no longer get the upper hand. Instead, the penal order with the closest connection to the case - mainly the place of commission - would apply, which can either be more lenient or more severe than other states' systems. ${ }^{126}$

Furthermore, the question of the EU's competence to prescribe supranational criminal provisions arises. Directly applicable regulations that include criminal provisions could namely imply that national courts would be obliged to apply other than national (i.e. nationally implemented) criminal law. ${ }^{127}$ In this case, member states would establish their penal authority by reference to a supranational legal order.

\section{The 'when' of criminal jurisdiction - When should the state en- force its penal authority?}

The distinction between a state's penal authority and judicial authority is especially important when considering the 'when' of criminal jurisdiction. The question of whether or not the states has penal authority ('if') and which law to apply ('how') mainly con-

124 See Greve, Danske straffebestemmelsers interlegale gyldighed: Træk af en forvirret retsudvikling, in Liber amicarum et amicorum Karin Cornils - Glimt af nordisk straffrätt og straffeprosessrett, eds. Elholm et al. (Jurist- og Økonomforbundets Forlag 2010) pp. 179-180 and Satzger 2012 op. cit. p. 9.

125 Jescheck \& Weigend 1996 op. cit. p. 164 and Satzger 2012 op. cit. p. 9.

126 See Greve 2010 op. cit. p. 180. On the other hand, the legal and practical problems with such a system should obviously not be underestimated, see e.g. Ambos 2008 op. cit. p. 69.

127 On the current legal possibilities for enacting supranational EU criminal law, see e.g. Satzger 2012 op. cit. pp. 48 ff. and Asp 2012 op. cit. pp. $141 \mathrm{ff}$. 
cern the legislative level. In this context, we can also speak of the state having 'abstract' jurisdiction, meaning that the state has a normative claim on penal authority, without anything being said about the concrete enforcement of this claim.

As already noted, state interests often overlap and states are in principle entitled to extend their penal authority also to extraterritorial circumstances, as long as they are able to demonstrate a meaningful connection. Consequently, international law accepts that the criminal jurisdiction (i.e. the penal authority) of states may overlap. Even though one could discuss whether or not some of the principles of jurisdiction are stronger than other ones - implying that 'weaker' claims should yield to 'stronger' ones - international law does not seem to provide a clear solution to this problem. ${ }^{128}$

First of all, states' unilateral regulation of their jurisdiction inevitably brings about situations where several states' claims on penal authority can cover the same act. Secondly, international conventions and EU legislation also result in 'jurisdictional networks' that give states overlapping penal authority.

However, it would obviously be unreasonable if states felt compelled to exercise judicial authority over all extraterritorial acts that are e.g. committed by their nationals, even though these acts fall within the scope of application of their criminal law. Abstract applicability of a state's criminal law (i.e. existence of penal authority) does not categorically imply concrete application (i.e. exercise of judicial authority). Thus, by laying claim to penal authority through the exercise of prescriptive jurisdiction, the state determines the outer legal limits of its judicial jurisdiction, but does not necessarily say anything about whether judicial authority should be exercised in concreto.

Thus the question arises: When should a state actually enforce its penal authority? This rather concerns the judicial level, i.e. the concrete exercise of judicial authority. If more than one state simultaneously decides to exercise judicial authority over the same act, we can be said to be dealing with a 'concrete' conflict of jurisdiction. In the words of the explanatory report to the European Convention on the Transfer of Proceedings in Criminal Matters: ${ }^{129}$

'A conflict of competence in concreto arises or exists, when the authorities of two or more States, competent under domestic law, simultaneously claim jurisdiction in the same case and actually start proceedings or, at least, indicate their intention to do so. It is not necessary that the competence of one of the States concerned should actually be contested; it is sufficient that two or more States are acting simultaneously and that there is a consequent overlapping of proceedings.'

128 See e.g. Henrich 1994 op. cit. pp. 77-78.

129 Explanatory report (Part IV, General remarks) to the European Convention on the Transfer of Proceedings in Criminal Matters (CETS No. 73). See also Vander Beken et al. 2002 op. cit. p. 18. 
Such conflicts of jurisdiction can have negative consequences for the efficiency of a state's criminal proceedings as well as for individuals that are thereby affected. Also, due to the fact that we have a functional transnational ne bis in idem rule - at least within the EU - only one state will be able to effectively enforce its penal authority: the state that first renders a final decision will prevent all other states from enforcing their penal authority in accordance with the principle of 'first come first served', even though it would perhaps have been more appropriate to handle the case in another state. ${ }^{130}$

As regards the national judiciary, the rules on jurisdiction prescribed by the state legislator can be regarded as a form of outer limits. Naturally, the judiciary cannot claim jurisdiction outside the limits of the state's penal authority, but can also be obligated to take further jurisdictional requirements into account in individual cases. One has to keep in mind that judicial jurisdiction is always exercised in individual cases, while the legislative power has as its task to prescribe general norms. The fact that a norm is applicable does not imply that it has to be applied.

In order to redress the overlapping penal authority of states, it can be up to the judicial authorities to decide to which extent the state should actually exercise its judicial authority. ${ }^{131}$ The judicial authorities may under certain circumstances - e.g. due to considerations of appropriateness, sovereignty or foreseeability - very well decide not to institute legal proceedings, although the offence as such is covered by the state's penal authority. ${ }^{132}$

Among all the offences that in principle fall under a state's penal authority, legal proceedings should only be initiated against those offences that affect the interests of the state in such a way that it is justifiable to initiate proceedings. The aim should always be to allocate the legal proceedings to the state that is best qualified to provide a fair trial. In order to carry out this selection, a requirement for initiating proceedings against - foremost extraterritorial - offences is often that a higher prosecutorial authority or higher state authority (e.g. the head of state) issues a prosecution order for the offence in question. ${ }^{133}$ For instance, according to chapter 1, section 12 of the Finnish Penal Code, a criminal case may generally not be investigated in Finland without a prosecution order by the Prosecutor-General, if the offence is committed abroad. ${ }^{134}$ This consideration on the judicial level does not affect the state's penal authority as such, but rather functions as a safety valve

130 See e.g. Klip, European Criminal Law - An Integrative Approach (Intersentia 2012) pp. 199-200.

131 See e.g. Swart, Jurisdiction in Criminal Law: Some Reflections on the Finnish Code from a Comparative Perspective, in Criminal Law Theory in Transition, eds. Lahti and Nuotio (Finnish Lawyers' Publishing Company 1992) p. 533.

$132 \quad$ See e.g Vander Beeken et al. 2002 op. cit. p. 18.

133 Träskman 1977 op. cit. p. 342.

134 Similar provisions are found e.g. in Chapter 2, section 5 of the Swedish Penal Code and section $153 \mathrm{c}$ of the German Code on Criminal Procedure. 
that makes it possible to assess whether or not concrete judicial authority should be exercised in individual cases. The possibility to balance the interests of involved states and individuals should naturally be ensured through legislation, but the actual assessment can only be conducted at the judicial level. The legislator cannot be expected to foresee every type of potential conflict of interests or rights beforehand. ${ }^{135}$

The possibility to refrain from prosecution means that the state's potentially extensive claim on penal authority in individual cases can be corrected by procedural means. ${ }^{136}$ The underlying aim is to take account of international principles of state sovereignty and potential conflicts of jurisdiction as well as the interests of individuals involved before proceedings are initiated. However, clear rules on which criteria to take account of when considering whether or not to initiate proceedings seldom exist in national law - decisions are made on a case-by-case basis. ${ }^{137}$

The problem has been discussed intensively especially with regards to EU member states, which are presupposed to practice a close legal cooperation based on mutual trust. At the European level, some cautious steps have undeniably been taken in order to remedy the problem of conflicts of jurisdiction. The Council Framework decision on prevention and settlement of conflicts of exercise of jurisdiction in criminal proceedings, adopted in 2009, only requires the member states to set up consultation proceedings with each other 'with the aim of achieving a consensus on any effective solution aimed at avoiding the adverse consequences arising from parallel proceedings', without actually obligating member states to reach a consensus. Neither does it provide any binding guidelines on how to choose the 'most appropriate' place for prosecution. Even though I do not share all the criticism directed at the framework decision, ${ }^{138}$ it is without doubt only a first and inadequate step towards solving the problem. Several noteworthy models for dealing

See Spiermann, Personalhøjhed, in Festskrift til Jørn Vestergaard, eds. Baumbach, Dam \& Toftegaard Nielsen (Jurist- og Økonomforbundets Forlag 2008) p. 457-458.

Werle \& Jeßberger 2007 op. cit. p. 464.

Cf. also Summary of the answers given in reply to the questionnaire on the situation where several Member States have jurisdiction to conduct criminal proceedings for the same facts of an alleged criminal offence, Council doc. 17553/08, COPEN 263, 5.1.2009, p. 6: 'Various Member States underlined that the cases/situations are dealt with on a case-by-case basis, depending on the results of the (direct) contacts between the competent authorities of the States concerned.'

Cf. e.g. Gebbie, Conflict of European Jurisdiction - A Matter of Concurrence, New Journal of European Criminal Law - Special Edition (2009), pp. 11-15, who argues that the framework decision undermines the rights of individuals affected by transnational proceedings. Personally, I believe that consultation proceedings regulated to a certain extent are better than completely unregulated ad hoc proceedings or a complete lack thereof. The problem of balancing the member states' interest in effective prosecution and the interests of individuals is a rather more comprehensive problem, characteristic for the whole area of cooperation in criminal matters within the EU, which cannot be remedied through one single instrument. 
with conflicts of criminal jurisdiction have already been proposed by legal scholars. ${ }^{139}$ Regardless of which way forward the EU chooses, an appropriate model to solve such conflicts requires above all a sufficient level of transparency and predictability.

\section{Conclusion}

The aim of this article has been to analytically 'dissect' the concept of criminal jurisdiction. I have argued that criminal jurisdiction first and foremost entails a claim on the right to punish by the state, which can be expressed as a claim on penal authority. When a state claims penal authority, it claims a right to penalize and punish certain behaviour in relation to individuals, but also in relation to other states. Since a state's claim on criminal jurisdiction brings the sovereign interests of other states to the fore, this claim must be in accordance with standards of international law. International law entitles the state to penal authority, provided that it is able to demonstrate a so-called 'meaningful connection' between itself and the behaviour it seeks to regulate. When the state lays claim to criminal jurisdiction, it consequently makes use of the penal authority it is entitled to. As a general rule, the state establishes its penal authority through the scope of application of its national criminal law. However, it is also conceivable that a state lays claim to penal authority through the use of other than national criminal law. In this case, the state would exercise its penal authority by reference to e.g. foreign or supranational criminal law. The fact that a certain act falls within the penal authority of a state does not, however, categorically imply that the state must or should enforce its penal authority. Since the penal authority of states frequently overlap, it would be unfeasible if all states having criminal jurisdiction over the same act would feel compelled to enforce their penal authority. In such cases of 'conflict of jurisdiction', the question of whether or not a state actually should attempt to enforce its penal authority in practice always requires further deliberation and balancing of interests

139 See e.g. Sinn et al., Draft models of a regulatory mechanism for the avoidance of jurisdictional conflicts, in Jurisdiktionskonflikte bei grenzüberschreitender Kriminalität - Ein Rechtsvergleich zum Internationalen Strafrecht, ed. Sinn (V\&R unipress 2012) pp. 597 ff., Böse, Meyer \& Schneider 2014 op. cit. pp. 333 ff. and Zimmermann, Strafgewaltkonflikte in der Europäischen Union (Nomos 2014) pp. 320 ff. See also the contribution by Frank Zimmermann in this issue. 